\title{
The Effect of Budgeting Towards Managerial Performance
}

\author{
I.B Made Putra Manuaba ${ }^{1}$, L.G.P Sri Ekajayanti ${ }^{2}$, I Kt Puja Wirya Sanjaya ${ }^{3}$ \\ Fakultas Ekonomi dan Bisnis, Universitas Warmadewa, Denpasar ${ }^{1,2,3}$
}

\{info@warmadewa.ac.id\}

\begin{abstract}
The involvement of personnel in the budget preparation process provide the accuracy that can be used as a standard in performance assessments. The participation of managers in motivating subordinates to improve company performance is vital. High level of organizational commitment supports performance measurement system, which is a tool of management used to increase either decision making quality or accountability. With the measurement of performance, the company is expected to survive, develop, and cope with competition. This aim of present study are determining the participation effect of budgetary, commitment of organizational, and motivation and performance of measurement systems on the performance of managerial in four star hotels within Badung Regency. A total of 90 four star hotels forms the population of this study. Also, the study used random sampling and analysis of regression of multiple linear in analysing data. The results revealed that (1) Participation in budgeting has effect which is positive and significant on performance of managerial, with a sig $t$ value of $0,000<0.05$. (2) Commitment of Organizational has effect which is positive and significant on performance of managerial, with a sig t value of $0,000<0.05$. (3) Motivation has effect which is positive and significant on performance of managerial, with a sig $t$ value of $0.022<0.05$. (4) The performance measurement system has effect which is positive and significant on performance of managerial, with a sig $t$ value of $0.006<0.05$.
\end{abstract}

Keywords: Participation in Budgeting; Organizational Commitment; Motivation; Performance Measurement Systems; Managerial Performance

\section{Introduction}

In an increasingly competitive business environment, it requires business actors to manage their business effectively and efficiently in order to be able to win the competition. Here the need to improve the quality of company performance to be able to compete in an effort to achieve the goals of each company which ultimately requires business actors including managers to improve their performance, including the ability to plan, coordinate, and control various activities and resources they have. According to (Wibowo, 2017) performance is the workers result who have a relationship which is strong with the goals of strategic of organizations, satisfaction of customer, and economic contribution. 
Position of managerial is expected to be able to produce the different performance of managerial from performance of employee. Performance of managerial is the managers performance in activities of managerial. Performance of managerial is a factor that is important used to improve the effectiveness of company.

In improving performance of company, it cannot be separated from the role of employees in the company. Conversely, employees who are able to produce good performance need a motivational boost from their superiors. Motivation can be developed if there is a will or arises from oneself (intrinsic motivation) and encouragement from superiors (extrinsic motivation) for certain goals (Maslow, 1994). Measurement of performance is a tool of management to increase the decision making quality and accountability, it is also used to assess either the goals or objectives achievement (Whittaker, 1993). With the existence of performance measurement, the company is expected to survive and keep existing competition and developments up. Likewise in the hotel business in Bali, to maintain the existence of the business, the hotel must always be able to improve its performance in all aspects. The existence of hotels in Bali cannot be separated from the flow of tourist visits to well-known tourist objects, Badung Regency is a tourist visit area that is most in demand by tourists and is also most often used for international level meetings, which are directly will greatly impact the development of hotels in Badung Regency.

The following is a description of previous research such as A. P. Dewi (2014); (Mia Sulistiari Putri \& Wijana Asmara Putra, 2015) who found that variables budget participation have an effect which is positive on performance of managerial, and commitment of organizational has an effect which is positive on performance of managerial, while Suhanda (2018); Wicaksono (2016) who tested the budgeting participation variable found that there was no influence on performance of managerial and commitment of organizational had an effect which is positive on performance of managerial. Then, Purnamaningsih (2017); S. Dewi (2017) found that the variable participation in budgeting and motivation has an effect which is positive on performance of managerial, while commitment of organizational has no effect on performance of managerial. The background above let the researcher determining the effect of participation of budgetary, commitment of organizational, and motivation and performance of measurement systems on the performance of managerial in four star hotels within Badung Regency.

\section{Research Method}

According to Tangen in (Nugroho, 2013), a good performance measurement system is a set of performance measures that provide useful information for the company, thereby helping to manage, control, plan and carry out the company activities. With the performance measurement existence, the company is expected to be able to survive and keep up with existing competition and developments. Performance is the employees result having a relationship which is strong with the strategic objectives of organization, satisfaction of customer, and economic contribution. Position of managerial is expected to be able to produce a different performance of managerial from performance of employee. Performance of managerial is the managers performance in activities of managerial, such as planning, investigation, coordination, evaluation, supervision, staffing, negotiation and representation (Wibowo, 2017).

Based on this concept, the hypothesis of this study is formulated into: 
H1: Participation in Budgeting has an effect which are significant and positive on managerial performance at Four Star Hotels in Badung Regency.

H2: Commitment of Organizational has an effect which is positive on performance of managerial at Four Star Hotels in Badung Regency

H3: Motivation has an effect which is positive on performance of managerial at Four Star Hotels in Badung Regency

H4: Performance of Measurement Systems have an effect which is positive on performance of managerial at Four Star Hotels in Badung Regency

The population in the study is a 4-star hotel in Badung Regency, which amounts to 90 hotels (BPS Badung Regency in 2017). The method of determining the sample used is random sampling, which is in the form of that is, cluster sampling is done by dividing the population into several groups (clusters) (Jogiyanto, 2007). In Badung Regency, there are only three subdistricts that have four-star hotels and only three hotels were selected in each district. Consideration is used as the basis for determination of the sample in this study was the compilers budget burdened budget targets, at each hotel obtained 5 respondents, manager accounting, manager front office, manager of food and beverages, marketing manager, and general manager, bringing the total of respondent as much as 45 people. The technique of analysis data used in this present study is analysis of multiple linear regression, was formulated into:

$\mathrm{Y}=\alpha+\beta 1 \mathrm{X} 1+\beta 2 \mathrm{X} 2+\beta 3 \mathrm{X} 3+\beta 4 \mathrm{X} 4+\mathrm{e}$

\section{Results and Discussion}

\subsection{Test Instruments}

\subsubsection{Validity Test}

Table 1. Recapitulation of Validity Test Results

\begin{tabular}{lccc}
\hline \multirow{2}{*}{ Variable } & \multirow{2}{*}{ Item } & \multicolumn{2}{c}{ Validity } \\
\cline { 3 - 4 } Participation in budgeting & X1.1 & Coefficient & Information \\
& X1.2 & 0.632 & Valid \\
& X1.3 & 0.538 & Valid \\
& X1.5 & 0.428 & Valid \\
& X1.6 & 0.339 & Valid \\
Organizational commitment & X2.3 & 0.590 & Valid \\
& X2.4 & 0.642 & Valid \\
& X2.5 & 0.576 & Valid \\
Motivation & X2.6 & 0.461 & Valid \\
& X3.1 & 0.493 & Valid \\
& X3.2 & 0.553 & Valid \\
& X3.4 & 0.652 & Valid \\
Performance measurement & X3.5 & 0.514 & Valid \\
system & X3.6 & 0.347 & Valid \\
& X3.7 & 0.724 & Valid \\
& X3.8 & 0.440 & Valid \\
& X4.1 & 0.743 & Valid \\
& X4 .2 & 0.677 & Valid \\
& X4.3 & 0.618 & Valid \\
\hline
\end{tabular}




\begin{tabular}{cccc}
\hline \multirow{2}{*}{ Variable } & \multirow{2}{*}{ Item } & \multicolumn{2}{c}{ Validity } \\
\cline { 2 - 4 } & X4.4 & Coefficient & Information \\
\cline { 2 - 4 } & X4.5 & 0.595 & Valid \\
X4.6 & 0.816 & Valid \\
Managerial performance & X4.7 & 0.486 & Valid \\
& Y1 & 0.647 & Valid \\
& Y2 & 0.558 & Valid \\
& Y3 & 0.692 & Valid \\
& Y4 & 0.551 & Valid \\
& Y5 & 0.784 & Valid \\
& Y6 & 0.561 & Valid \\
\hline
\end{tabular}

The table above, can be seen that all of the variables have a correlation coefficient above 0.30 . This shows that the statement items in the instrument of research are valid.

\subsubsection{Reliability Test}

An instrument will be reliable, if the instrument has a Cronbach Alpha value of more than 0.60 .

Table 2. Recapitulation of Reliability Test Results

\begin{tabular}{lcc}
\hline \multicolumn{1}{c}{ Variable } & Cronbach's AlphaBudgeting & Information \\
\hline Participation (X1) & 0.652 & Reliable \\
Organizational commitment (X2) & 0.697 & Reliable \\
Motivation (X3) & 0.714 & Reliable \\
Performance measurement system (X4) & 0.769 & Reliable \\
Managerial performance (Y) & 0.749 & Reliable \\
\hline
\end{tabular}

The results test of reliability shows that a coefficient value of Cronbach Alpha above 0.60 is owned by all of research instruments have so that the instrument is reliable, so it is worthy of being used as a research instrument.

\subsection{Test of Classical Assumption}

\subsubsection{Test of Normality}

The aims of test of normality is to see the data used in the study which have been distributed normally. To look for whether the residuals are distributed normally or not, one of them is by performing a non-parametric Kolmogorov-Smirnov statistical test.

\begin{tabular}{llr}
\multicolumn{2}{c}{ Table 3. Asymp Value. Sig. (2-tailed) for the } \\
\hline \multicolumn{2}{c}{ One-Sample Kolmogorov-Smirnov Test } \\
\hline $\mathrm{N}$ & $\begin{array}{c}\text { Unstandardize } \\
\text { d Residual }\end{array}$ \\
\hline Normal Parameters & & 45 \\
& & .0000000 \\
Most Extreme Differences & Mean & .22728781 \\
& Std. Deviation & .112 \\
& Absolute & .112 \\
& Positive & -.112 \\
Kolmogorov-Smirnov Z & Negative & .753 \\
\hline
\end{tabular}




\begin{tabular}{lr}
\hline \multicolumn{2}{c}{ One-Sample Kolmogorov-Smirnov Test } \\
\hline & $\begin{array}{c}\text { Unstandardize } \\
\text { d Residual }\end{array}$ \\
\hline $\begin{array}{lr}\text { Asymp. Sig. (2-tailed) } \\
\text { a. Test distribution is Normal. }\end{array}$ & .622 \\
\hline
\end{tabular}

Based on the SPSS output, the Asymp value was obtained. Sig. (2-tailed) 0.622 which is huge than 0.05 . This showed that the residuals of data are distributed normally.

\subsubsection{Test Multicollinearity}

The method to determine the Multicollinearity presence in the model of regression is visible from the tolerance and variance inflation factor (VIF) value. In the table below, the calculation results for values are tolerance and VIFless than the number 10 and values tolerance greater than 0.1 , so that there is no Multicollinearity in the model of regression.

Table 4. Multicollinearity Test Results

\begin{tabular}{|c|c|c|c|c|c|c|}
\hline & \multirow{2}{*}{ Model } & \multicolumn{2}{|c|}{$\begin{array}{l}\text { Unstandardized } \\
\text { Coefficients }\end{array}$} & \multirow{2}{*}{$\begin{array}{c}\begin{array}{c}\text { Standardized } \\
\text { Coefficients }\end{array} \\
\text { Beta }\end{array}$} & \multicolumn{2}{|c|}{$\begin{array}{c}\text { Collinearity } \\
\text { Statistics }\end{array}$} \\
\hline & & B & $\begin{array}{l}\text { Std. } \\
\text { Error }\end{array}$ & & Tolerance & VIF \\
\hline \multirow[t]{10}{*}{1} & (Constant)-2771 & & 2436 & & & \\
\hline & $\mathrm{X} 1.0$ & .204 & & & .926 & 4,997 \\
\hline & & .552 & & & & \\
\hline & & .200 & & & & \\
\hline & $\mathrm{X} 2.0$ & .189 & & & & 1,041 \\
\hline & & .593 & & & & \\
\hline & & .257 & & & & \\
\hline & & 3,892 & & & & \\
\hline & $\mathrm{X} 3.0$ & -.120 & .050 & -.134 & .940 & 1.064 \\
\hline & $\mathrm{X} 4.0$ & -.158 & .055 & -.263 & .358 & 2,791 \\
\hline
\end{tabular}

\subsubsection{Heteroscedasticity Test}

Test Heteroscedasticity in this study seen from the figure scatterplot. The results of the heteroscedasticity test can be known into:

Scatterplot

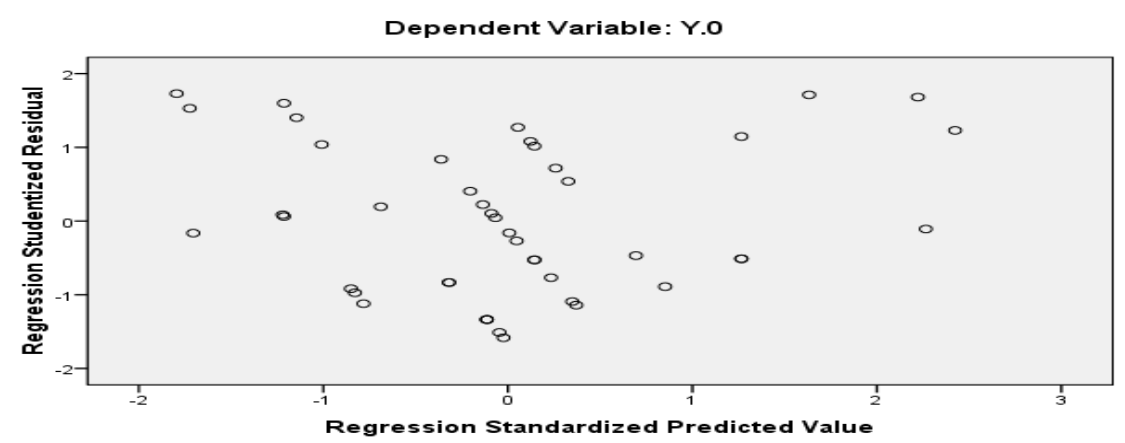

Fig. 1. Heteroscedasticity test Results 
Based on the figure, it is known that the data points are spread out and a pattern is not formed, therefore there is no heteroscedasticity.

\subsection{Analysis of Multiple Linear Regression}

Model used to analyze the variables-variables that affect managerial performance is a model of analysis of multiple linear regression with SPSS.

\begin{tabular}{|c|c|c|c|c|c|c|c|c|}
\hline & \multirow{2}{*}{ el } & \multicolumn{2}{|c|}{$\begin{array}{c}\text { Unstandardized } \\
\text { Coefficients }\end{array}$} & \multirow{2}{*}{$\begin{array}{c}\begin{array}{c}\text { Standardize } \\
\text { d } \\
\text { Coefficients }\end{array} \\
\text { Beta }\end{array}$} & \multirow{2}{*}{$\mathbf{t}$} & \multirow{2}{*}{ Sig. } & \multicolumn{2}{|c|}{$\begin{array}{c}\text { Collinearity } \\
\text { Statistics }\end{array}$} \\
\hline & & B & $\begin{array}{c}\text { Std. } \\
\text { Error }\end{array}$ & & & & Tolerance & VIF \\
\hline \multirow[t]{17}{*}{1} & (Constant) & 2,771 & 2,436 & & 1,138 & .262 & & \\
\hline & $\mathrm{X} 1.0$ & .204 & & & 4,529 & & .926 & 4,997 \\
\hline & & 0,552 . & & & & & & \\
\hline & & 000 & & & & & & \\
\hline & & .200 & & & & & & \\
\hline & $\mathrm{X} 2.0$ & .189 & & & 5,515 & & & 1,041 \\
\hline & & 0,593 . & & & & & & \\
\hline & & 000 & & & & & & \\
\hline & & .257 & & & & & & \\
\hline & & 3,892 & & & & & & \\
\hline & $\mathrm{X} 3.0$ & .050 & & & 2,383 & 0,120 & .940 & 1,064 \\
\hline & & 0,134 . & & & & & & \\
\hline & & 022 & & & & & & \\
\hline & $\mathrm{X} 4.0$ & .055 & & & 2,885 & & 0,158 & 2,791 \\
\hline & & 0,263 . & & & & & & \\
\hline & & 006 & & & & & & \\
\hline & & .358 & & & & & & \\
\hline
\end{tabular}

Regression analysis results on the table 5 can be prepared following equation of regression: $\mathrm{Y}=0,552 \mathrm{X}_{1} 0,593 \mathrm{X}+{ }_{2}+0,134 \mathrm{X}_{3}+0,263 \mathrm{X}_{4}$. Accordingly to the equation of the lines of multiple linear regression, it provides information that:

a. The regression coefficient value of the budgeting participation variable is positive 0.552 , which means that an increase in budget participation $\left(\mathrm{X}_{1}\right)$ will be followed by an improvement in performance of managerial (Y)

b. The regression coefficient value of the organizational commitment variable is positive 0.593 means that with increasing organizational commitment $\left(\mathrm{X}_{2}\right)$, managerial performance $(\mathrm{Y})$ will also increase.

c. The regression coefficient value for the motivation variable is positive 0.134 , which means that increased motivation $\left(\mathrm{X}_{3}\right)$ will be followed by an increasing in performance of managerial $(\mathrm{Y})$

d. The regression coefficient value of the performance measurement system variable is positive 0.263 , which means that an increase in the performance measurement system $\left(\mathrm{X}_{4}\right)$ will be followed by an increase in performance of managerial (Y). 


\subsection{Testing of Hypothesis (t-test)}

This $t$ test commonly shows how much the variable of one explanatory or independent personally influence in describing the variable of dependent variation. This test can be finished by comparing the level of significance. If the significance value less than 0.05 indicates that alpha $\mathrm{H}_{0}$ rejected and $\mathrm{H}_{a}$ accepted.

\subsection{Determination Coefficient (R2) Test}

Test of coefficient of determination was conducted to determine how far the ability of the variable of independent (independent) explains the variable of dependent (dependent), that can be known from the $\mathrm{R}^{2}$ value is adjusted $\mathrm{R} 2$.

Table 6. The Coefficient of Determination (R2) Test

\begin{tabular}{lrrrr}
\hline Model & R & R Square & $\begin{array}{c}\text { Adjusted R } \\
\text { Square }\end{array}$ & $\begin{array}{c}\text { Std. Error of } \\
\text { the Estimate }\end{array}$ \\
\hline 1 & $.939^{\mathrm{A}}$ & .869 & & .881 \\
\hline
\end{tabular}

According to the table above, value adjusted $\mathrm{R}^{2}$ of 0.869 , this means by $86.9 \%$ participation budgeting, commitment of organizational, motivation, and measurement systems of performance affect performance of managerial while the remaining $13.1 \%$ is explained by another variables which is not including in this present study.

\section{Conclusion}

It can be concluded from the research result above that 1) Budgeting participation has an effect which are positive and significant on performance of managerial, with a sig $t$ value of $0.000<0.05$. 2) Commitment of organizational has an effect which is positive and significant on performance of managerial, with a sig t value of $0.000<0.05$. 3) Motivation has an effect which are positive and significant on performance of managerial, with a sig t value of 0.022 $<0.05$. 4) The performance measurement system has an effect which are positive and significant on performance of managerial, with a sig t value of $0.006<0.05$.

\section{References}

[1] Dewi, A. P. (2014). Pengaruh Partisipasi Anggaran Dan Komitmen Organisasi Terhadap Kinerja Manajerial (Studi Kasus Pada Universitas Widyatama Bandung). Jurnal Fakultas Ekonomi Universitas Widyatama.

[2] Dewi, S. (2017). Pengaruh Partisipasi Penyusunan Anggaran, Komitmen Organisasi Dan Motivasi Terhadap Kinerja Manajerial. Jurnal Riset Akuntansi (JUARA), 7(2).

[3] Jogiyanto. (2007). Metodologi Penelitian Bisnis. Yogyakarta: BPFE.

[4] Maslow, A. H. (1994). Motivasi dan Kepribadian (Teori Motivasi dengan Pendekatan Hierarki Kebutuhan Manusia). Jakarta: PT BPP.

[5] Mia Sulistiari Putri, N., \& Wijana Asmara Putra, I. (2015). Pengaruh Partisipasi Penganggaran Pada Kinerja Manajerial. E-Jurnal Akuntansi, 12(2), 435-451. 
[6] Nugroho, W. A. (2013). Analisis Pengukuran Kinerja Perusahaan dengan Konsep Balanced Scorecard (Studi Kasus PT Wijaya Karya). Universitas Islam Negeri Syarif Hidayatullah.

[7] Purnamaningsih, F. A. (2017). Pengaruh Partisipasi Anggaran, Komitmen Organisasi Dan Sistem Pengukuran Kinerja Terhadap Kinerja Manajerial (Studi Pada Badan Keuangan Daerah Kabupaten Sukoharjo). INSTITUT AGAMA ISLAM NEGERI SURAKARTA. https://doi.org/10.1017/CBO9781107415324.004

[8] Suhanda. (2018). Pengaruh Partisipasi Anggaran, Motivasi Kerja, Dan Komitmen Organisasi Terhadap Kinerja Manajerial Pada Dinas Skpd Kabupaten Bintan. Universitas Maritim Raja Ali Haji, 1-16.

[9] Whittaker, J. (1993). The Government Performance Result Act. Educational Services Institute.

[10] Wibowo. (2017). Manajemen Kinerja (Edisi Keli). Jakarta: PT Raja Grafindo.

[11] Wicaksono, G. (2016). Pengaruh Partisipasi Penyusunan Anggaran Terhadap Kinerja Manajerial Pada Sekolah Menengah Negeri di Tegal. Esensi, 6(2), 199-212. https://doi.org/10.15408/ess.v6i2.3575 